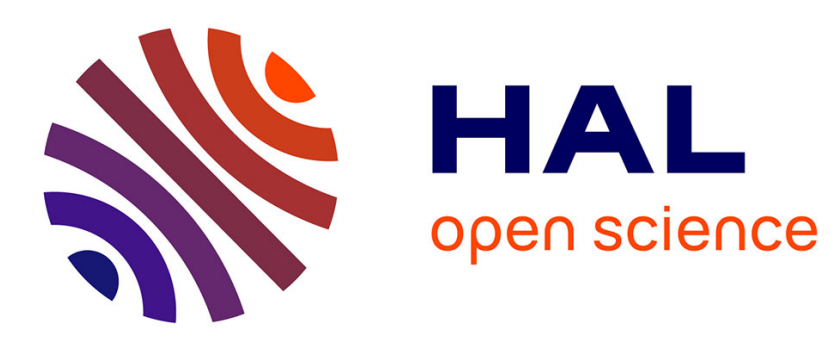

\title{
Nonstoichiometric Ba Hexaferrites, Prepared by Partial or Complete Ion Exchange
}

\author{
G. Litsardakis, A. Stergiou, J. Georgiou, D. Samaras
}

\section{To cite this version:}

G. Litsardakis, A. Stergiou, J. Georgiou, D. Samaras. Nonstoichiometric Ba Hexaferrites, Prepared by Partial or Complete Ion Exchange. Journal de Physique IV Proceedings, 1997, 07 (C1), pp.C1533-C1-534. 10.1051/jp4:19971218 . jpa-00254890

\section{HAL Id: jpa-00254890 https://hal.science/jpa-00254890}

Submitted on 1 Jan 1997

HAL is a multi-disciplinary open access archive for the deposit and dissemination of scientific research documents, whether they are published or not. The documents may come from teaching and research institutions in France or abroad, or from public or private research centers.
L'archive ouverte pluridisciplinaire HAL, est destinée au dépôt et à la diffusion de documents scientifiques de niveau recherche, publiés ou non, émanant des établissements d'enseignement et de recherche français ou étrangers, des laboratoires publics ou privés. 


\title{
Nonstoichiometric Ba Hexaferrites, Prepared by Partial or Complete Ion Exchange
}

\author{
G. Litsardakis, A.C. Stergiou*, J. Georgiou** and D. Samaras \\ Department of Electrical \& Computer Engineering, Aristotelian University, 54006 Thessaloniki, Greece \\ * Department of Physics \\ ** Department of Chemical Engineering
}

\begin{abstract}
Non-stoichiometric hexaferrite particles ( $M$ type structure) in the form of single crystals or fine particles have been prepared by complete or partial ion exchange from $\beta^{\prime \prime}$-ferrite precursor phase. Complete exchange yields directly the hexaferrite phase. Partial exchange maintains the $\beta$ " structure and heating at $\mathrm{T}>600^{\circ} \mathrm{C}$ is necessary for the $\mathrm{M}$ type structure to be formed. The crystal stnucture of non-stoichiometric hexaferrites is described as an M-type hexaferrite with $\beta$-type intergrown cells. The Curie temperature is that of stoichiometric $\mathrm{BaFe}_{12} \mathrm{O}_{19}, \mathrm{~T}_{\mathrm{c}}=460^{\circ} \mathrm{C}$. Saturation magnetization in a field of $20 \mathrm{kOe}$ at room temperature is $35-65 \mathrm{emu} / \mathrm{g}$ and the coercive field $\mathrm{H}_{\mathrm{c}} \approx 1.5-2.2 \mathrm{kOe}$. The higher values are obtained after annealing, which also increases grain size from 50 to $200 \mathrm{~nm}$.
\end{abstract}

\section{INTRODUCTION}

$\mathrm{Ba}$ hexaferrite fine particles have been extensively studied for recording applications. The very high coercivity of $\mathrm{BaFe}_{12} \mathrm{O}_{19}$ is ususally reduced by partial substitution of $\mathrm{Fe}^{3+}$ by $\mathrm{Co}-\mathrm{Ti}$ ions [1], which however reduces the saturation magnetization and Curie temperature. Non-stoichiometric $\mathrm{Ba}$ hexaferrites containing $\mathrm{Co}, \mathrm{Zn}, \mathrm{Mg}$, or $\mathrm{Ni}$, have been alternatively examined as low coercivity hexaferrite particles. They are synthetized from $\beta\left(\mathrm{KFe}_{11} \mathrm{O}_{17}\right)$ or $\beta^{\prime \prime}\left(\mathrm{K}_{2} \mathrm{Fe}_{10.5} \mathrm{Co}_{0.25} \mathrm{O}_{17}\right)$ ferrites by ion exchange in $\mathrm{BaCl}_{2}-\mathrm{KCl}$ melt, and annealing at $\mathrm{T}>850^{\circ} \mathrm{C}[2,3]$. They have also been prepared as mixed (Ba, $\left.\mathrm{K}\right)$ hexaferrites by partial ion exchange in aqueous solution or in $\mathrm{Ba}\left(\mathrm{NO}_{3}\right)_{2}-\mathrm{KNO}_{3}$ melt at $\mathrm{T}=650^{\circ} \mathrm{C}$ [4]. The synthesis processes, crystal structure, morphology and magnetic characteristics are summarized in the present work.

\section{RESULTS}

The $\beta^{\prime \prime}$ ferrites that are used in the ion exchange reactions are prepared by the organometallic precursor method [5]. $\mathrm{KCl}$ and $\mathrm{FeCl}_{3}$ mixed in proportion $2 \div 10.5$ are mixed and small amounts of $\mathrm{Co}^{2+}$ or $\mathrm{Mg}^{2+}$ or $\mathrm{Zn}^{2+}$ ions are added in the solution. By heating at $\mathrm{T}>700^{\circ} \mathrm{C}$ the $\beta^{\prime \prime}$ ferrite $\mathrm{K}_{2} \mathrm{Fe}_{10.5} \mathrm{Co}_{0.25} \mathrm{O}_{17}$ is formed. The obtained phases are examined by chemical analysis and X-ray diffraction. The precursor $\beta^{\prime \prime}$ ferrites are transformed to $\mathrm{Ba}$ hexaferrites by ion exchange and annealing. Depending on the exchange conditions, exchange reaction is partial or complete, resulting in the final formation of non stoichiometric hexaferrite containing either both $\mathrm{Ba}$ and $\mathrm{K}$, or only $\mathrm{Ba}$, as non transition metal cations.

Complete exchange of $\mathrm{K}$ by $\mathrm{Ba}$ takes place in high temperature $\mathrm{BaCl}_{2}-\mathrm{KCl}$ or $\mathrm{BaCl}_{2}-\mathrm{NaCl}$ melt, at $\mathrm{T} \geq 750^{\circ} \mathrm{C}$ for $24 \mathrm{~h}$, producing non stoichiometric hexaferrites in fine powder or single crystal form. At that temperature exchange is fast and the transformation of the $\beta^{\prime \prime}$ phase into magnetic hexaferrite is direct. Exchange time and annealing temperature affect the magnetization by rearranging $\mathrm{Fe}$ ions in the transformed structure. Annealing at $\mathrm{T}=900^{\circ} \mathrm{C}$ also increases grain size from 50 to $200 \mathrm{~nm}$ [3].

Partial exchange of $\mathrm{K}$ by $\mathrm{Ba}$ is accomplished in an aqueous solution of $\mathrm{Ba}\left(\mathrm{NO}_{3}\right)_{2}$, at $\cdot \mathrm{T}=40,60,80^{\circ} \mathrm{C}$, for $2 \mathrm{~h}[4]$ The study of partial exchange has revealed that hexaferrite formation proceeds in two separate stages. According to chemical analysis results, there are about $0.5 \mathrm{Ba}$ and $0.6 \mathrm{~K}$ per formula unit after the exchange, while X-ray diffraction shows that the $\beta^{\prime \prime}$ structure is not altered. The amount of $\mathrm{Ba}$ increases and the amount of $\mathrm{K}$ decreases with the exchange temperature. The exchanged $\beta^{\prime \prime}$ ferrite is transformed at a second stage into $\mathrm{M}$-type hexaferrite which contains both $\mathrm{Ba}$ and $\mathrm{K}$, by heating at $\mathrm{T}>600^{\circ} \mathrm{C}$. At $\mathrm{T}=700^{\circ} \mathrm{C} \mathrm{Fe}{ }_{2} \mathrm{O}_{3}$ is formed, increasing with the annealing temperature. 
The sum of $\mathrm{Ba}+\mathrm{K}$ atoms (1.1), as well as the sum of their charges (1.6), are lower than expected for a $\beta$ " type structure. For example, in $\beta^{\prime \prime}$ aluminas they are close to 1.65 and 1.8 respectively. The deficit may be explained if we assume that in the aqueous solution $\mathrm{K}^{+}$ions have also been exchanged by $\mathrm{H}_{3} \mathrm{O}^{+}$. Such an exchange has been observed during a simple washing of the precursor $\beta^{\prime \prime}$ ferrite, evidenced by chemical analysis and DTG. A possible chemical formula for the exchanged $\beta^{\prime \prime}$ ferrite is $\mathrm{K}_{0.65} \mathrm{Ba}_{0.5}\left(\mathrm{H}_{3} \mathrm{O}\right)_{0.25} \mathrm{Fe}_{10.5} \mathrm{Co}_{0.25} \mathrm{O}_{17}$. This time, however, the presence of $\mathrm{H}_{3} \mathrm{O}$ cannot be detected by DTG, because the variation is $\sim 5 \%$. The exchange of $\mathrm{K}^{+}$ions by $\mathrm{H}_{3} \mathrm{O}^{+}$can also explain the formation of $\mathrm{Fe}_{2} \mathrm{O}_{3}$ during annealing, by a mechanism similar to that proposed for the annealing of the washed precursor phase: The dehydrated $\beta^{\prime \prime}$ phase, deficient in large cations, is unstable and rejects the excess Fe atoms in order to form a stable $\beta$ "-structure [4]. It should be noticed that $\mathrm{Fe}_{2} \mathrm{O}_{3}$ does not occur when the exchange is performed in a melt [3].

Single crystals of $\beta$ " ferrite have been exchanged in a eutectic $\mathrm{Ba}\left(\mathrm{NO}_{3}\right)_{2}-\mathrm{KNO}_{3}$ melt, at temperature and time lower than those required for complete exchange, $T=650^{\circ} \mathrm{C}$, for $15 \mathrm{~min}$. The $\beta^{\prime \prime}$ structure is maintained after the exchange and it is transformed, by heating at $1000^{\circ} \mathrm{C}$, into non-stoichiometric M-type hexaferrite with chemical formula $\mathrm{K}_{0.31} \mathrm{Na}_{0.64} \mathrm{Ba}_{0.71} \mathrm{Fe}_{10.55} \mathrm{Mg}_{0.29} \mathrm{O}_{17.3}[6]$.

The crystal structure has been studied in both partially and completely exchanged single crystals [6,7]. The unit cell is hexagonal with $a \approx 5.9 \AA$ and $c \approx 23.2 \AA$. The predominant character of the structure, positions and populations of atoms, are those of stoichiometric $\mathrm{BaFe}_{12} \mathrm{O}_{19}$ (magnetoplumbite-M type). After structure refinement, the final description is not effected in the space group $\mathrm{P}_{3} / \mathrm{mmc}$ of $\mathrm{BaFe}_{12} \mathrm{O}_{19}$, but in groups of lower symmetry, such as $\mathrm{P} \overline{6}$. This structure modification is due to deviations from stoichiometric composition: the number of $\mathrm{Fe}$ atoms is reduced and the number of larger atoms (Ba, $\mathrm{K}, \mathrm{Na}$ ) is increased. Besides M-type cell, there are also $\beta$-type intergrown cells, without Fe atoms in the characteristic of $M$ structure bipyramidal site of the mirror plane. In $\beta$-type cells $\mathrm{Ba}$ and $(\mathrm{K}, \mathrm{Na})$ atoms are in $\mathrm{BR}$ and aBR positions of the mirror plane. Furthermore, $\mathrm{K}$ and $\mathrm{Na}$ atoms substitute partially for $\mathrm{O}$ atoms in the spinel block, while $\mathrm{Fe}$ atoms have been located in intersticial positions as well. The percentage of M-type cells is determined by the Fe population in the characteristic bipyramidal site, and it is found lower in partially exchanged compounds, $66 \%$ compared to $75 \%$ of completely exchanged compounds.

The Curie temperature of the final hexaferrite, determined from constant field (500 Oe) magnetization versus temperature curves, is for all samples that of stoichiometric M-type Ba hexaferrite, $460( \pm 5)^{\circ} \mathrm{C}$. Magnetisation at $20 \mathrm{kOe}$ is lower than that of the standard Ba-M, ranging from 35 to $65 \mathrm{emu} / \mathrm{g}$. The coercive field, measured on compacted samples, is $\mathrm{Hc} \approx \mathrm{I} .5-2.2 \mathrm{kOe}$. The higher values of $\sigma_{20}$ and $\mathrm{Hc}$ have been obtained after annealing at $\mathrm{T}=800-1000^{\circ} \mathrm{C}$. Annealing at higher temperatures does not improve magnetization but decreases $\mathrm{Hc}$ due to the increase of particle size. Partially exchanged hexaferrites exhibit low magnetization values, due to the lower percentage of M-type cells and the presence of $\mathrm{Fe}_{2} \mathrm{O}_{3}$ impurities. In general, magnetization is set by the percentage of M-type cells in the structure, that is the iron content of the bipyramidal sites, but in completely exchanged hexaferrites it is even higher, possibly because of induced magnetization to the antiferromagnetic $\beta$-type cells $[2-4]$.

\section{CONCLUSION}

Ba ferrite particles with non-stoichiometric composition and modified magnetic characteristics are prepared by ion exchange reactions from $\beta$ "-ferrite precursors. Ion exchange in aqueous solution is an interesting method for studying the hexaferrite formation process. Is is softer but yields partially exchanged hexaferrites with lower magnetization. The potential advantages of this method are raised by the inevitable formation of $\mathrm{Fe}_{2} \mathrm{O}_{3}$ impurities, probably resulting from an exchange of $\mathrm{K}$ by $\mathrm{H}_{3} \mathrm{O}$. The crystal structure is $M$-type with $\beta$-type intergrown cells and minor modifications in the positions of the atoms to account for the stoichiometry deviations. Compared to standard $\mathrm{Ba}$ hexaferrite's values, in non stoichiometric hexaferrites magnetization reaches $85 \%$, Tc is the same and Hc is considerably lower.

\section{Acknowledgments}

The General Secretariat for Research and Development (Greece) is acknowledged for financial support.

\section{References}

[1] Pernet M, Obradors X., Vallet M., Hernadez T. and Germi P., IEEE Trans.Magn. 24 (1988) 1898

[2] Samaras D., Georgiou J., Panas S. and Litsardakis G., IEEE Trans.Mag. 26 (1990) 18-20

[3] Litsardakis G., Stergiou A.C., Georgiou J., Sklavounos S., Samaras D., Pernet M. and Germi P., J.Mag.Mag.Mat. 120 (1993) 58-60

[4] Litsardakis G., Stergiou A.C., Georgiou J. and Samaras D., J.Sol.St.Chem. (1996) to be published

[5] Licci F. and Besagni T., IEEE Trans.Magn. 20 (1984) 1639

[6] Stergiou A.C, Samaras D. and Litsardakis G., to be published

[7] Stergiou A.C, Samaras D., Kalogirou O., Vincent H. and Bekka A., Sol.St.Ionics 50 (1992) 11 - 18 